\title{
Shopping mall crisis and a new perspective in the framework of the polycentric multiuse metropolitan model
}

\author{
F. D. Moccia \\ Department of Urban Design and Planning, Federico II University, Italy
}

\begin{abstract}
The suburban shopping mall acts as the core of suburban development on a low density basis and a large land consuming low density sprawl. This human environment has been criticized especially today, when scientists are warning the global population about the dangers of climate change.

In the dynamics of metropolitan development, retail competition and changing client demands, the life of a suburban shopping mall has a time of growth, an apex and a decline until closure. Old facilities are substituted by brand new ones multiplying land consumption and dictating new patterns of mobility.

In the perspective of retrofitting suburbs with the objective of sustainable human settlement, we need some strategies of change for suburban shopping malls.

This paper will present the work of the city planning workshop of the University Federico II (Naples) to face regional housing demand. Following the New Urbanism theory of redevelopment of the shopping mall in multiuse urban development, exercises of urban design are being explored to figure out whether the epitome of suburbanization could change into a compact, high density city core.

Keywords: shopping mall redevelopment, New Urbanism, metropolitan area, sustainable development.
\end{abstract}

\section{Introduction}

City planning has been more and more challenged, in recent years by ecological problems, the United Nation worldwide program on climate change being the 
last step. One of the most known public events organized by the French President Sarkozy on the issue was in March 2009; to imagine a future scenario for the capital. The metaphoric title was legranparis, meaning both the big French metropolis and the ecological challenge. Ten groups of planners and multidisciplinary consultants joined in a shared metropolitan model better defined by Rogers [1].

It supposes that a sustainable urban system is based on the concentration of people and economic activities in a polycentric metropolis, saving agricultural land and natural ecosystems. There, high density nodes can minimize the citizens' journeys by car and favour mass public transit at low greenhouse gas emission. This centre would have to be multiuse and socially integrated in a way that pubic connecting space enhances pedestrian and cycling mobility, social encounter, and healthy urban climate (Moccia [2]). These concentrations permit an urban infrastructure aimed at saving energy and integrating local energy production from renewables. The green infrastructure tries to complete the cycles of the natural elements, first of all, for meteoric water to save, clean, reuse, and manage (Moccia [3]).

To follow this model means to make a radical move from the last decade of urban developments. According to the theory and evidence of city development, city growth seems more similar to an explosion (Indovina et al. [4]) with people moving from the core to the suburbs on a longer distance and in any direction, wherever family car can go. At the climax of such human settlement organization, a long list of problems has been created that can be grouped around some main shortcomings: individual development is weakening social life and cohesion, the consumption of natural resources is far higher than whatever ecosphere may supply to human needs. The last calculation of the ecological footprint shows that the whole surface of the earth can no longer assure the metabolism of its natural resources, given the consumption of the same made by mankind. The new urban frontier which appeared to Joel Garreau as a window open on the USA future is showing the nightmare sealed in its more deep structure (a revenge for planner thinking marginalized in the essay of the famous journalist who preferred developer intuitions) (Garreau [5]).

Housing sprawl is to stop and redevelop in more compact, high density, mixed-use developments. Enclosed regional shopping malls are the by-product and the support of suburban sprawl. They provide the centre and meeting point of suburbanites kindly offered by retailers in trade-off for buying at their firms. Low density settlement with a transportation system based on private car and a good highway network can draw customers from long distances in such numbers to feed distribution organizations so large as to enjoy the economy of scale. Research findings do not state a deterministic linkage between the decline of suburbs and the shopping mall crisis, but the mutual support in the development process; nevertheless, this is the time where an increasing consciousness of the unsustainability of suburbs and the decay of regional shopping malls occurs. 


\section{Enclosed shopping malls and suburbs}

The first enclosed regional shopping mall was designed by Victor Gruen, an Austrian refugee, in Edina, just outside Minneapolis, in 1954. It had 72 stores and two anchor department store tenants, Donaldson's and Dayton's, grouped, over two floors around a galleria and a covered skylight central plaza with a fishpond, enormous sculpted trees, a 21-foot cage filled with brightly-colored birds, balconies with hanging plants, and a café.

"Southdale was not a suburban alternative to downtown Minneapolis. It was the Minneapolis downtown you would get if you started over and corrected all the mistakes that were made the first time around" (Gladwell [6, p. 125]).

The architect general plan surrounded the enclosed box, whose perimeter walls were completely blind, with houses, schools, parks, offices; in other words with an urban fabric as he remembered of his own native city, Vienna; but that plan was never realized, and the big box was left in an empty plan of asphalt. With its attractiveness and flaws, it becomes an archetype for thousands of malls in the USA and all over the world.

"Shopping centers and strip malls became what urban planners call "catalytic," meaning that developers weren't building them to serve existing suburban communities; they were building them on the fringes of cities, beyond residential developments, where the land was cheapest" (Gladwell [6, p. 126]). There, they could generate other new suburbs, fuelling the already existing sprawl.

One more evidence of the linkage of shopping malls and suburb development is offered by the research of Ownbey et al. [7] that explores location variables and their impact on gross rents for neighborhood shopping centers. The authors attempt to explain the superior performance of centers based on location alone, forming a multivariate model of location variables based on the professional opinions of appraisers, investors, lenders, leasing brokers and sales brokers. The research result states that as a city expands toward the suburbs, inner city and first ring suburbs lose location value. In other words, shopping mall follows people's residence and their suburban sprawl.

\section{Regional shopping mall crisis}

In Italy we are still at the stage of large shopping mall development, and we can identify just some cases of failure. The most known is Centro Commerciale Pratilia, open in the city of Prato, near Florence in 1978. The admired building had underground parking, about 100 shops and two anchor department stores. On the roof was located a swimming pool, tennis courts and disco music. By the mid-1990s half the shops were closed. Its crisis deepened in 1997 when a bigger and more modern, with more parking lots, mall "I Gigli" opened at little distance away. In 2003, there being only three shops left, it was definitively closed. In this case, failure of the mall had been competition in the same industry.

In the United States, the country where earlier shopping malls were built and the wider sprawl occurred, closure is much more widespread. The collection of 
hundreds of sad stories and gloomy pictures is the site: deadmalls.com. In January 2001 Global Strategic Real Estate Research Group published research for the Congress of New Urbanism (CNU) that investigated older, economically obsolescent regional malls in the United States (US) - referred to as "Greyfield malls." they found that $7 \%$ of the existing malls in the USA may be classified as greyfield and an additional $12 \%$ may be supposed to move to the same status within five years. One critical variable distinguishing Greyfield and nonGreyfield malls is sales-per-square-foot less or equal to $\$ 150$, although other variables as size, age, occupancy, tenant mix, and trade area demographics confirm the same differences. According to different definitions of regional malls, in the USA there are 1,689 or 2,076 malls consequently Greyfield malls are respectively, 114 or 140 and the malls that could become dead in the following five years 203 or 249 . The reasons why a mall may decline are attached mainly to its age:

"A typical Greyfield mall is 32 years old with the last major expansion or renovation approximately 13 years ago. On average, identified Greyfield malls have 22 competing retail centers within five miles with an aggregate 2.33 million square feet of competition. Another reasonable explanation for the existence of Greyfield malls is that new retail formats in newer centers have captured the market share. In summary, there are a variety of reasons why malls decline: from changes in trade area competition and demographics, to poor management and tenant behavior" (Congress for the New Urbanism [8, p.6]).

The only context condition explored in this research involves the socioeconomic condition of the nearby neighborhoods. There are two types associated with declining shopping malls: a) areas inhabited by newly formed households with moderate incomes living in affordable housing, consisting of older, singlefamily homes and duplexes in urbanized areas; b) established and stable with moderate-income households, middle-aged and older married couples. We may suppose that such neighborhoods are in the inner urban aging circles and may benefit from a wave of returning affluent residents toward the inner metropolitan cores.

This report is dated 2001. The situation became worst in the following years, as an article of The Week declared in 2009, March 26, demonstrating that that research was quite optimistic: "More than 400 of the 2,000 largest malls in the U.S. have closed in the past two years. The last new major mall in the U.S. opened in 2006, and only one big mall is scheduled to open this year - the troubled Xanadu mega-mall in Rutherford, N.J." What has increased are two factors already considered: the reduction of family revenue and e-commerce competition.

\section{Big box reuse}

When a shopping mall closes, it will give a blighted building, deprive the community of a commercial service, a gathering and walking place, and tax revenue for local government. The value of the real estate fall down damaging investors and landlords. Property owners and municipalities often take action to 
overcome the crisis. There are many ways they can follow, the first one being the reuse of big boxes (Christensen [9]). In September 2001 an abandoned K-Mart was turned into a museum (Spam Museum) dedicated to the canned meat produced in the close by city of Austin. In addition, the old store hosts offices of the Hormel, the firm that produced the packaged meat, employing on the site 100 people. The two storey building covers a surface of 16,500 square feet, and uses one floor for the museum and the upper for offices. In Laramy, WY, a Wal-Mart was abandoned in approximately 1997, and turned into a Charter School in the summer of 2002. Now shops and a playground have been added. The Grand Union building of Latham, NY, was abandoned in 1996, as Grand Union grocery stores began to close all over the northeast. It had been empty for about 5 years when the Grace Fellowship bought the building in 2001. There was a solid year of renovation before the church moved in, in May of 2002. The church contains a 1500 seat sanctuary, over 15 classrooms, 2 cafes, a youth club, several meeting rooms and offices, and is home to several clubs and meetings taking advantage of its position at the exit n. 25 of the NY interstate 87 . The Princeton Fitness and Wellness Center has been open in a renovated Grand Union grocery store since May 19, 2003. The building, 52,000 square feet large, is home to over 6,000 members and 140 employees and is equipped with three swimming pools, two studios for classes, a physical therapy unit, offices, conference centers, two large exercise rooms with cardio/free weight equipment, and a day spa. Flea markets are the simpler e economically viable reuse. Other reuse found is the conversion of old warehouses in: a) Indoor Raceway, b) Head Start Child and Family Development Program, c) Comprehensive Medical Center, d) College Library and e) Guitar Center Home Depot.

Sometimes the big box reuse is not a simple change of function of an already existing building to renovate, but becomes a strategic change in an urban revitalization. In this case the reuse is an action inside an urban redevelopment plan. The Granby Street Apartments are a part of a downtown revitalization project that is happening in Norfolk, and are filled inside a large, one-room, freestanding building, at one time, the Ames Department store. Also the Nelson County Justice Center, located on the site of a former Wal-Mart, has become the magnet of a new development in Bardstown, whose tourist industry is a primary source of income (Christensen [10]).

\section{Shopping mall redevelopment}

Closure of shopping malls is an internal dynamics and not the end of that industry, according to the studies of the CNU [11], combined with urban dynamics. Old enclosed shopping malls have too small lots and cannot enlarge, following the trend of bigger facilities; their location misses the accessibility requirements; are changing the social mix of the surrounding population. On the other side, new opportunities take place: as an effect of city enlargement, the site reaches a more central location, land prices increase, and the large surface of the parking lots appear "underperforming asphalt" (Dunham-Jons and Williamson [12]). 
A new term to define a development site was added to Greenfields used when development occurs on open land and to Brownfields when former industrial contaminated sites are involved. The new word is Greyfields "hinting at the sea of asphalt separating a regional or super-regional shopping mall from its town. Greyfields are economically obsolete malls and other sites that offer large infill redevelopment opportunities, without the contamination found on Brownfield sites" (CNU [9, p.7]).

The CNU research finds 12 cases of redevelopment and chooses to study six of them from which to learn a lesson of success. There are some factors coming from the changing shopping style of consumers that increasingly shows a preference for open air shopping and mix-use developments. This favors a shift to a city center model giving an opportunity to the CNU urban ideal of a sustainable high density model.

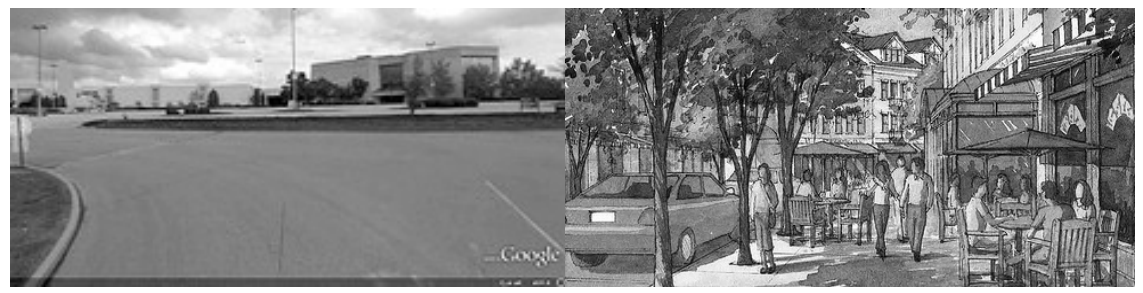

Figure 1: A view of Jamestown Mall before and after its redevelopment.

A key question is the urban space form. The introversion of the enclosed mall has inside the pedestrian connection designed as interior space. Out of the box, land is devoted to parking and becomes a simple asphalt surface. The result of putting outside the walking connection has an astonishing effect. Open space has to be designed, managed and lived in.
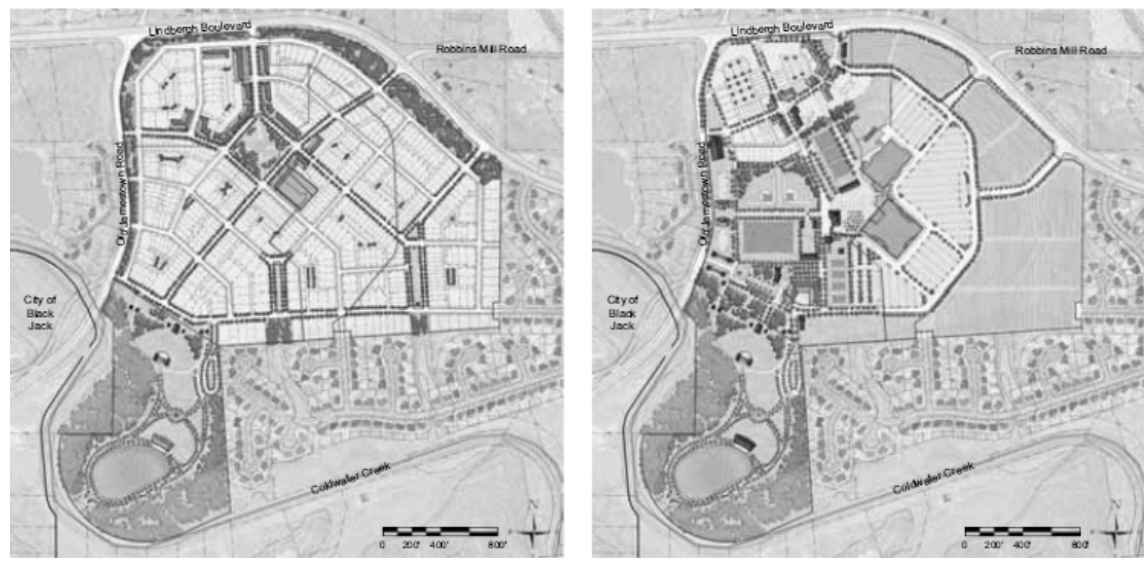

Figure 2: Two scenarios set for Jamestown Mall redevelopment. 
Local government too has an important role because redevelopment is more complex than the single retail initiative. That is to change regulatory use plan, assemble land, organize different actors, and fill the redevelopment in a bigger design. An exploration of this complexity is a task of proper research of planning and is perceived through scenario study. An example is the work made by Dover, Kohl \& Partners, supported by firms of economic advisers and civic engineering for the S. Louis County for the redevelopment of the Jamestown Mall. The four scenarios elaborated have references to wider economic and social conditions, but are also an exploration of the site potential. How many people can be accommodated in different types of housing, what businesses can be put in, how circulation may occur, what natural elements can be restored in the urban fabric? (S. Louis County [13]).

There are many changes possible of the large lot at one time occupied by the mall. Many others are not considered in the scenario selected, and can be found in the list of the already considered study of the CNU. In some redevelopment, the simple infilling of houses, or the design of a new tree lined boulevard, added to the former stores has been enough to create a new urban environment; in another, the demolition of the big boxes was necessary to open new streets and plan a piece of traditional city. In Denver suburb, on the site of the former Villa Italia mall there are now 22 blocks of the new Belmar development. The redevelopment scheme includes 1.1 million square feet of retail space, 900,000 square feet of office space, a 250-key hotel, 1,300 residential units (1/3 rental apartments and $2 / 3$ for-sale condominium), and parking for 9,000 vehicles, as well as an events center, a 16-screen movie theater, an arts exhibition venue, and nine acres of parks, plazas, and other public spaces.

This review acknowledges some trends in the retail industry, what Greyfield redevelopment is about, how the new scheme may be more sustainable. In the end, we have also acknowledged that public action needs to explore future solutions through scenario construction.

\section{Academic explorations}

The workshop of city planning in the University Federico II has assumed the sustainable model described in the introduction to face the emerging territorial problems of the metropolitan area of Naples. While there is the highest density in the country, housing demand until 2020 is estimated at up to 160,000 homes. Land consumption has become a major problem where open spaces and agricultural land is in short supply. The densification solution requires the identification of potential development areas that are not Greenfield. The already defined Greyfield is an important resource. Students of the Greyfield redevelopment suggest making comprehensive plans so that destinations may be given in a regional framework (Dunham-Jons and Williamson [12]).

In the metropolitan area there are 11 regional shopping malls, but only one can be classified as declining. The question changes in some way, and examined factors need to be rearranged. We can assume that a shopping mall has a life cycle towards decay and a remedy to rehabilitate the mall is to convert in a mix- 
use complex. The well known advantages go from the shopper's preference to the concentration of people that can enjoy the facility also with pedestrian access. To plan a mix-use redevelopment without waiting for the shopping mall closure is a strategy to strengthen its duration.

Development of the parking lot area does not hinder shopping mall operations. The introduction of housing and other uses may be designed without reducing the number of vehicles parking, using the vertical integration.

To explore the potentials of such hypothesis three of the 11 shopping malls with the larger size were selected. The solutions to the larger of them are presented in this paper. On the two sides of a highway, that join Naples to Caserta, and are the main growth axes, there is a shopping mall and a life style development, both with huge asphalt area for parking.

The plan will be implemented in steps, so that lessons can be learned during construction. Investment is managed as a revolving fund. Car use can be strongly limited because there is a railway line on the border of the area and a station can easily be built, integrated in the regional transit system. Inside the development is proposed light transit proportional to the local transportation demand.

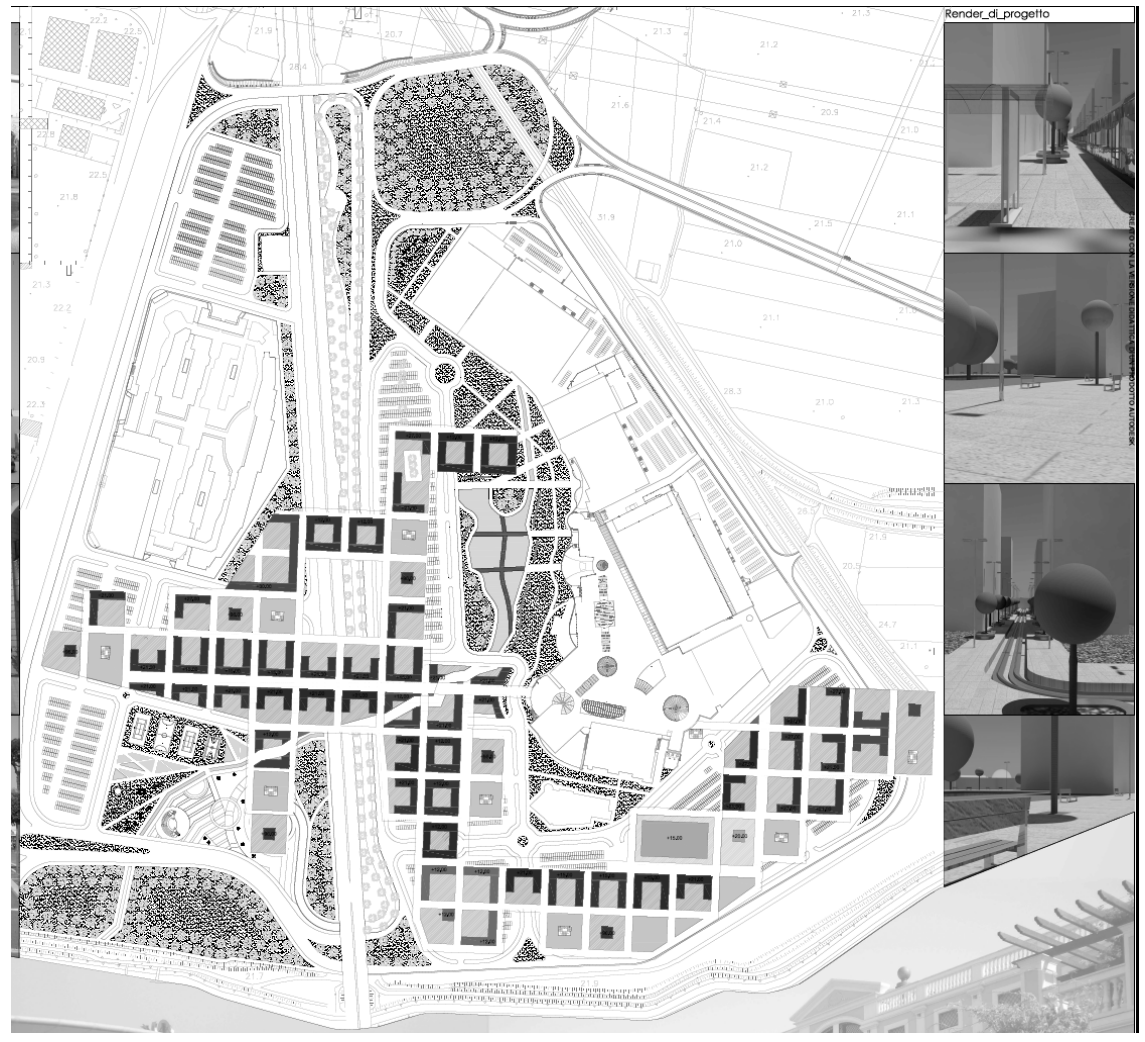

Figure 3: Centro Commerciale Campania, first scenario (students: Adamo E., Canettieri F., Contiello, M. Cordova G.). 
The urban fabric designed across the highway aims to connect the shopping mall and the life style centre using their parking lots above. Walkways towards the shopping mall galleria try to keep a continuity of pedestrian mobility coming from the inside environment of the enclosed shopping mall to the open space of the urban fabric. Because all the connections are above the parking lots, there is a complete division between the car and mechanical transportation mode and the cycling and pedestrian one.

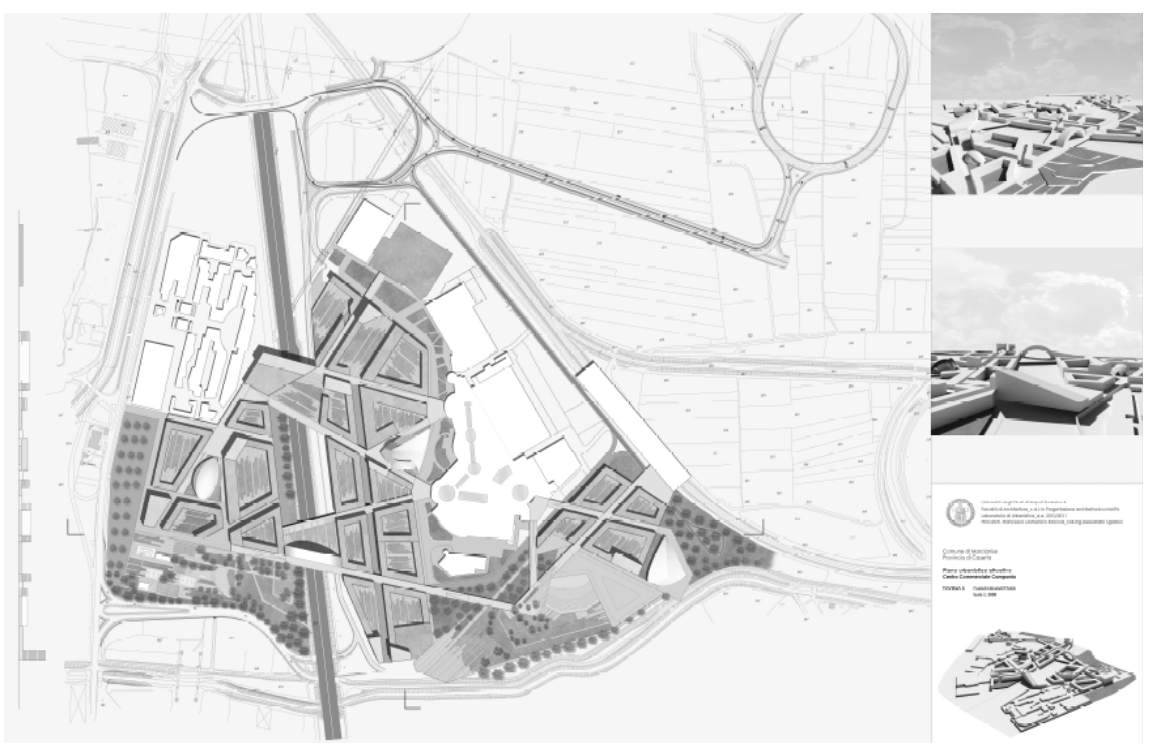

Figure 4: Centro Commerciale Campania, second scenario (students: Bianco A., Boni F., Girardi F., Marotta F.).

Public facilities are sized in proportion to inhabitants, according to the regional planning rules, and increased with private facilities, mainly in the culture sector (music theater, art exposition hall, research, vocational education). In fact, restaurants, cinema theatre, and other amusements are already in place. Working space is office and light industry. The position of these public or community building in the urban grid is in key sites for the interior urbanscape and for the long distance landscape. They act as reference points for the orientation and identity of the place. Most of them face a public square or are at important crossroads, others are higher than surrounding buildings and can be seen from a long distance. For the identity of the development an important perception is from the people driving on the highway at high speed.

There are many types of housing buildings. Some are highrise, others apartment buildings, or townhouses combined in a block. Urban morphology has a regular grid of streets and well defined urban spaces, but there is a wide range of housing opportunity still in an orderly city form. In the meantime, regular streetscape has the opportunity of a variety of architecture. 


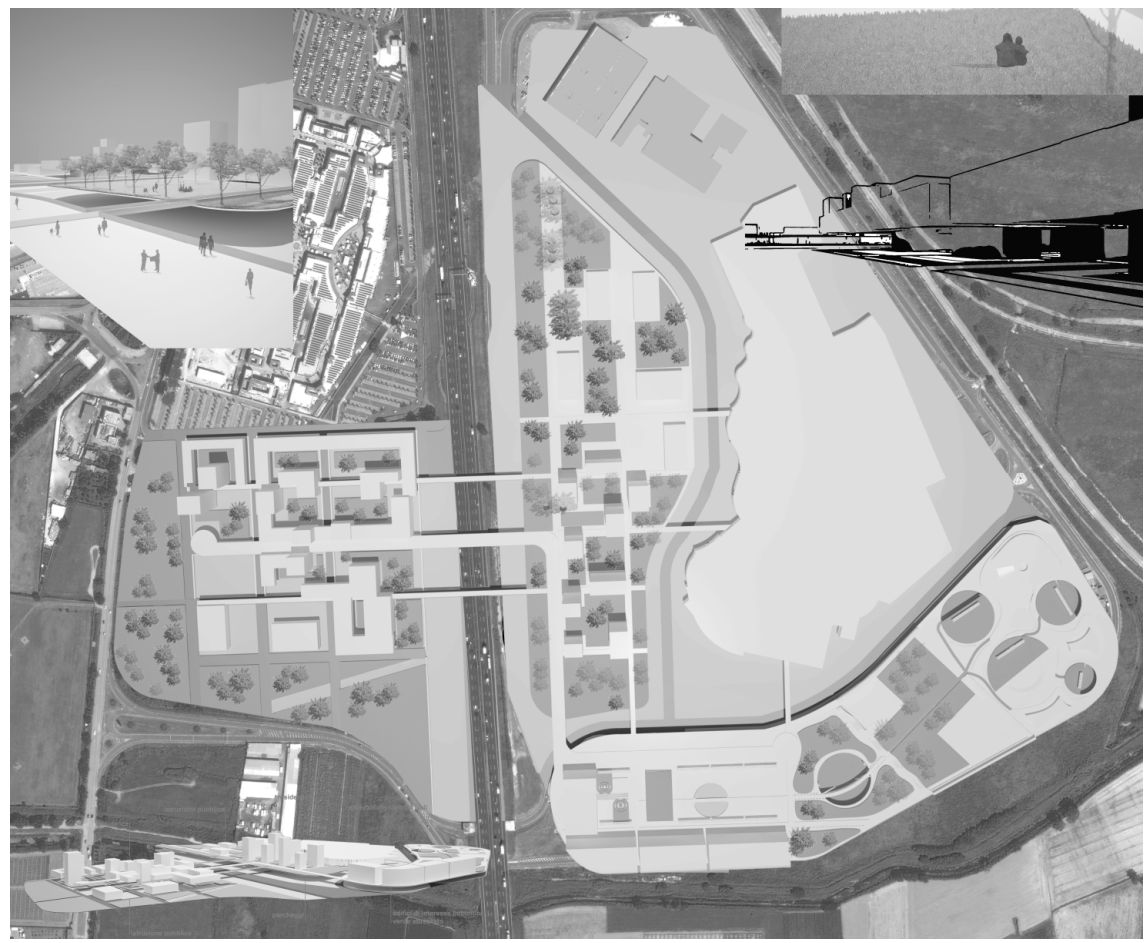

Figure 5: Centro Commerciale Campania, third scenario (students: Carullo P., De Simone S.).

On the southern side of the area flows a small river. Landscaping starts from there and is embedded in the urban fabric. Stormwater is collected on the roofs of any building, some collected in tanks, other parts flow in open swales along the pathways feeding shrubs and grass. Then the flows convey into ponds in parks with depurative and infiltration effects (Jorgensen [14]). The general rule is to divide stormwater collection and management of the sewage is reserved only for black water.

Urban waste is separated, recycled and collected. The wet organic waste is treated in plants that collect the methane gas produced by its decomposition and used to generate energy in three generation systems where the heat is collected to feed networks of telewarming-cooling. The other by-product will be used to fertilize urban gardens and orchards for a fresh supply of produce.

\section{Conclusion}

The benefits of such redevelopments are twofold: on one side, it is a strategy against shopping mall decay (in fact, clients in a short range increase and other economic activities are put in); on the other side it is an anti-sprawl strategy. We will have transit developments with a train station to which any dweller can 
walk. To the shopping and leisure facilities already existing will be added social services, schools sport facilities, parks always a walking distance. Green infrastructure assures a sustainable management of stormwater and natural landscaping of public spaces. Garbage separation and collection is processed so that the result is reuse of materials, generation of energy (in the three-generation mode), worming, and manuring. Building use energy saving technologies. Green energy production is integrated in the urban fabric.

This high density development can accommodate housing demand without consuming more non urbanized land. It is recognized that the metropolis has a new organization where the shopping mall is a new core area, magnet of large suburbs. This attraction can be used to concentrate housing and people in sustainable mixed use poles. The process may go further forward with the abandonment of the furthermost fringes and the increase of natural and farmland in place of blighted low density housing.

\section{References}

[1] Equipe "Rogers Stirk Harbour \& Partners", Livret chantier n.1, 2, 27-022009, www.legrandparis.net

[2] F.D. Moccia, L'urbanistica nella fase dei cambiamenti climatici. Urbanistica, 140 (LXI), pp. 95-102, 2009.

[3] F.D. Moccia, Infrastruttura verde. Urbanistica Informazioni, 232(XXXVIII), pp. 28-29, 2010.

[4] Indovina F., Fregolent L., Savino M. (eds), L'esplosione della città, Edizione Compositori: Bologna, 2005.

[5] Garreau J., Edge City, Life in the New Frontier, Doubleday: New York, 1991.

[6] Gladwell M., Annals of Commerce. The Terrazzo Jungle. Fifty years ago, the mall was born. America would never be the same. The Newyorker, pp. 120-127, March 15, 2004.

[7] Ownbey, K. L., Kyle D. \& Harvey H. S.. The effect of location variables on the gross rents of neighborhood shopping centers. The Journal of Real Estate Research, 9 (1), pp. 111- 123, 1994.

[8] Congress for the New Urbanism, Greyfield Regional Mall Study. PWC, 2001.

[9] Christensen J., Big Box Reuse, The MIT Press: Cambridge, Mass., 2008.

[10] Christensen J., Big Box Reuse, www.bigboxreuse.com.

[11] Congress for the New Urbanism, Malls into Mainstreets. An in-depth guide to transforming dead malls into communities, 2005.

[12] Dunham-Jons E., Williamson J., Retrofitting Suburbia. Urban Solution for Redesigning Suburbs, Hoboley, NJ: John Wiley \& Sons, 2009.

[13] S. Louis County, Missouri, Jamestown Mall Area Plan, May 2011.

[14] Jorgensen S. E. (ed), Applications in Ecological Engineering, Elsevier: Amsterdam, 2009. 